\title{
Problem solving skill: Effectiveness on think pair share with comic
}

\author{
Isti Dwi Mustafia ${ }^{1}$, Sri Adi Widodo ${ }^{2 *}$ \\ ${ }^{1,2}$ Universitas Sarjanawiyata Tamansiswa, Yogyakarta, Indonesia
}

\begin{tabular}{|c|c|}
\hline ARTICLE INFO & \multirow{7}{*}{$\begin{array}{l}\text { A B S T R A C T } \\
\text { The purpose of this study was to determine the effectiveness of the } \\
\text { Think Pair Share with the comic of } 7 \text { th grade students' ability to } \\
\text { solve mathematical problems in SMP } 9 \text { Yogyakarta. This type of } \\
\text { research is an experiment with posttest-only-control design. The } \\
\text { sample used in the study determined by cluster random sampling } \\
\text { technique. The results of hypothesis testing using the t-test showed } \\
\text { that } t_{\text {count }} \text { is greater than } \mathrm{t}_{\text {table, in other words, Think Pair Share }} \text { learning with comic generates better mathematical problem solving } \\
\text { skills to students than think pair share only. Furthermore, Think } \\
\text { Pair Share with the comic is more effective when viewed from the } \\
\text { ability to solve problems. }\end{array}$} \\
\hline Orig & \\
\hline doi: 10.18860/ijtlm.v1i2.7181 & \\
\hline Keywords: & \\
\hline Problem Solving Skill, Think & \\
\hline Pair & \\
\hline Effectiveness & \\
\hline
\end{tabular}

(C) 2018 IJTLM. All rights reserved.

*Corresponding author.
E-mail: sriadi@ustjogja.ac.id

How to cite: Mustafia, I.D \& Widodo, S.A. (2018). Problem Solving Skill: Effectiveness on Think Pair Share With Comic. International Journal on Teaching and Learning Mathematics, 2(1), 76-83.

\section{INTRODUCTION}

In general, every individual has various kinds of problems that related to learning material and in everyday life. In this regard, students cannot avoid a problem, especially with mathematical problems. By avoiding mathematical problems, students are considered to think practically in solving problems. Even though learning mathematics, students must understand mathematical concepts that are abstract and are expected not to use a practical mindset. Lots of students experience difficulties in learning mathematics; this is because mathematics is an abstract science (Suwarto \& Purnami, 2018). As a result, mathematics learning becomes a learning that is very difficult to understand so that students' cognitive abilities become less optimal must possess the basic abilities of mathematics to master science and technology as well.

Similar to cognitive abilities in general, students' mathematical problem-solving skills also show results that are not optimal (Fuad et al., 2017; Huda, 2016; Kristanti et al., 2018). Though one of the mathematical abilities that must be possessed by students is the ability to solve mathematical problems (Choi et al., 2014; Elliott et al., 2001; Erozkan, 2013; Pardimin \& Widodo, 2016; Peter, 2012), because the problem-solving ability is the (Acharya, 2017; Afifah \& Ningrum, 2018; Amalia et al., 2016; Indaryati \& Jailani, 2015; Martyanti \& Suhartini, 2018), coupled with the negative perception of students towards mathematics teachers, causing students to be lazy to learn mathematics (Awuah et al., 2013; Gazali, 2016). Mathematics has an essential role in everyday life such as training someone to reason and using logic more (Saragih, 2006). Thus, every student heart of learning mathematics. Mathematical problem solving is one 
of the basics of skills that students need to have (Putra et al., 2017). The ability to solve significant problems in learning mathematics because problem-solving skills obtained in mathematics teaching are usually used to solve problems encountered in everyday life (Widodo et al., 2018). Based on observations conducted at SMP 9 Yogyakarta, information was obtained that students tend to memorize formulas rather than understanding mathematical concepts, so that students can be categorized as careless tendencies in solving mathematical problems (Aisyah et al., 2018; Bernard et al., 2018). In dealing with the problem students immediately think of using formulas, even students tend to use practical ways to solve problems compared to concepts to solve them In other words, students are more concerned with the results of answers compared to the process of solving problems.

Many ways can be used to improve students' mathematical problem-solving skills. one of them by using a learning model that is in accordance with the material to be delivered is very necessary, to be able to support students 'thinking power in students' mathematical problemsolving abilities. One learning model that can be used is Think Pair Share. This learning model is thought to improve students' cognitive abilities such as the ability to solve mathematical problems (Arends \& Kilcher, 2010; Husna, Ikhsan, \& Fatimah, 2013). In Think Pair Share learning, teachers are expected to prepare learning devices that can support the learning process for the better. One learning device that can be developed before learning is the media (Widodo, 2018).

Learning media is a tool for conveying messages to students, in this case, the message to be delivered in the form of learning material (Baruah, 2018; Hartsell, \& Yuen, 2006; Lin, Chen, \& Liu, 2017). The results of the study indicate that learning media can influence the effectiveness of learning (Bulut et al., 2016). One of the media that can be used in learning mathematics is comics (Buchori \& Setyawati, 2015; Herbst et al., 2011; Tatalovic, 2009; Toh et al., 2017; Widodo et a.l, 2018). The use of comics in mathematics learning can be used to concretize abstract mathematical concepts. So students are easier to understand the concepts given by the teacher. Moreover, junior high school students, most of whom have not yet reached the formal development phase, are in great need of supporting tools in learning that can help them understand mathematical material.

The aim of this study was to determine the differences in mathematical problem-solving abilities between the think pair share plus comic and think pair share only in class IX student SMP 9 Yogyakarta. Where TPS learning used refers to the syntax of cooperative learning are Thinking, pairing, and sharing (Antika, 2018). Comics that are used as learning media in the form of books can be used as an alternative teaching material in learning mathematics in quadrilateral.

\section{METHOD}

The method used in this study was an experiment with posttest-only-control design. In this design, there are two groups, each chosen randomly based on a homogeneous class (Creswell, 2012, Creswell \& Creswell, 2017). The first group is the experimental group, namely Think Pair Share learning using comic media, while the learning control group Think Pair Share does not use comics.

The research sample was selected using cluster random sampling technique, which is a technique used when the population does not consist of individuals, but consists of individual groups or clusters (Budiyono, 2003; Creswell, 2012; Sugiyono, 2016). Based on this sampling 
technique, obtained the VII-A class as many as 34 students as the experimental class and VII-E class students as many as 34 students as the control class by applying TPS learning only.

Two variables were used in this study, they were independent and dependent variables. Independent variables were variables controlled by researchers. While the dependent variable was something that is observed to determine the changes due to the influence of the treatment of think pair share with comic on learning outcomes. The data in this study were obtained through a test instrument in the form of a description question to measure students' mathematical problem-solving abilities with flat quadrilateral. Indicators in mathematical problem-solving in this study are adjusted to the stages of problem-solving from Polya, namely understanding the problem, planning a solution, implementing the plan, and re-examining the results obtained (Polya, 1973). As for the description of each stage of problem-solving from the policy, it is presented in Table 1.

Table 1. Scoring Rubric Mathematical Problem Solving Test

\begin{tabular}{|c|c|c|}
\hline The Polya Stage & Score & Indicator \\
\hline \multirow[t]{4}{*}{$\begin{array}{l}\text { Understand the } \\
\text { problem }\end{array}$} & 3 & $\begin{array}{l}\text { Students can write (express) what is known and asked from the } \\
\text { problem raised clearly }\end{array}$ \\
\hline & 2 & Students only write (express) what is known or what is asked \\
\hline & 1 & $\begin{array}{l}\text { students write down data/concepts/ knowledge that is not related to } \\
\text { the problem being proposed so that students do not understand the } \\
\text { question posed }\end{array}$ \\
\hline & 0 & $\begin{array}{l}\text { students do not write anything down, so students do not understand } \\
\text { the meaning of the problem posed }\end{array}$ \\
\hline \multirow[t]{3}{*}{ Make a plan } & 2 & $\begin{array}{l}\text { Students write enough conditions and necessary conditions } \\
\text { (formulas) from the problem proposed and use all information that } \\
\text { has been collected }\end{array}$ \\
\hline & 1 & $\begin{array}{l}\text { students tell/write down steps to solve the problem but are not } \\
\text { complicated }\end{array}$ \\
\hline & 0 & students do not tell/write steps to resolve the problem \\
\hline \multirow[t]{5}{*}{ Carry out the plan } & 4 & $\begin{array}{l}\text { Students carry out the ideas that have been made, use the steps to } \\
\text { solve the problem correctly, there is no procedure error, and no } \\
\text { algorithm/calculation errors occur }\end{array}$ \\
\hline & 3 & $\begin{array}{l}\text { Students carry out the plan that has been made, use the steps to solve } \\
\text { the problem correctly, and there is no procedure error, but an } \\
\text { algorithm/calculation error occurs }\end{array}$ \\
\hline & 2 & $\begin{array}{l}\text { Students carry out the plan that has been made, but a procedure error } \\
\text { occurs }\end{array}$ \\
\hline & 1 & $\begin{array}{l}\text { Students carry out the plan that has been made, but a procedure error } \\
\text { and algorithm/calculation error occur }\end{array}$ \\
\hline & 0 & Students are unable to carry out the plans that have been made \\
\hline \multirow{2}{*}{$\begin{array}{l}\text { Look back at the } \\
\text { completed solution }\end{array}$} & 1 & Students re-examine the answers \\
\hline & 0 & Students do not re-check answers \\
\hline
\end{tabular}

(Source: Widodo \& Turmudi, 2017)

T-test were used for data analysing technique in this study. This test is used to test the proposed hypothesis. The hypothesis proposed in the study is that students using Think Pair Share assisted by comics have better mathematical problem-solving abilities compared to using Think Pair Share.

\section{RESULTS AND DISCUSSION}

The mathematical problem-solving test contains a rectangular problem. This problems consist of five questions. Problem to find is a problem in the way of determining or obtaining a value or a 
particular object that is unknown in the question and fulfilling the conditions or conditions that are in accordance with the problem, the objective that is asked or unknown (terms), and data or the information provided is an essential part of the problem looking for and must be understood and recognized well at the beginning of solving the problem (Polya, 1973). By using the problem-solving test scoring model referring to table 1 , it is found that the ideal maximum score is $5 \times 10=50$ and the ideal minimum score is $5 \times 0=0$. Considering the ideal average and ideal standard deviation, five categories were arranged as shown in Table 2.

Table 2. Ideal Normal Curve Criteria

\begin{tabular}{cl}
\hline Interval & \multicolumn{1}{c}{ Criteria } \\
\hline $\bar{x} \geq 37.5$ & Very High \\
$29.17<\bar{x} \leq 37.5$ & High \\
$20.83<\bar{x} \leq 29.17$ & Medium \\
$12.51<\bar{x} \leq 20.83$ & Low \\
$\bar{x} \leq 12.51$ & Very low \\
\hline
\end{tabular}

Based on mathematical problem-solving-ability data, the average score of experimental group (TPS with Comic) is 21.85. Hence, this group was categorized in medium criteria. The average score of control group (TPS only) is 19.00 . Hence, this group was categorized in medium criteria..

The t-test was conducted to test the research hypothesis, namely "Think Pair Share assisted by comics have better mathematical problem-solving abilities compared to using Think Pair Share ". To test this required prerequisite tests that must be fulfilled are normality tests and homogeneity tests. One of the statistical tests that can be used to test normality is the Liliefors test. The calculation results show that 1 count is 0.059 . Seeing the $\mathrm{L}_{\text {table }}$ of 0.109 , it can be concluded that the sample comes from a population that is normally distributed. The second requirement test is the homogeneity test. One of the statistical tests that can be used to test the variance homogeneity is the $F$ test. The result of the calculation shows that Fcount $=1.112$. See table $\mathrm{F}$ on the $5 \%$ significance level found that $\mathrm{F}$ table is 1.84 , so it can be concluded that the variance of several populations are the same or homogeneous because Fcount is less than Ftable.

Table 3. Summary of hypothesis tests

\begin{tabular}{llrrrc}
\hline Group & $\mathrm{N}$ & $\bar{x}$ & $S_{p}$ & $t_{\text {count }}$ & $t_{\text {table }}$ \\
\hline Experiment & 33 & 21.85 & \multirow{2}{*}{5.3} & 2.19 & \multirow{2}{*}{1.997} \\
Control & 33 & 19.00 & & & \\
\hline
\end{tabular}

Based on Table 3, the calculation of the hypothesis test using the t-test is obtained that $t_{\text {count }}$ is 2.19. In table $t$ using a significance level of $5 \%$ and $n$ of 63 obtained for 1.997. Because $t_{\text {count }} \geq t_{\text {table }}$ It can be concluded that there are differences in the average between classes using the think pair share plus comic with a group that uses the think pair share only. To determine which group has better performance, it is necessary to look at the averages in each group. From the calculation, it was found that the mean of the experimental group was 21.85 while the mean of the control group was 19.00 , so it can be concluded that students' ability to solve mathematical problems using think pair share with comic media is better than think pair share only.

A learning is said to be effective if it meets the requirements (1) the presentation of high student learning time is devoted to teaching and learning activities, (2) the average behavior of 
carrying out high tasks among students, (3) the determination of the content of the teaching material with the student's abilities, and (4) developing a friendly and positive learning atmosphere (Triyanto, 2009). Also, the effectiveness of learning is a learning process that achieves learning outcomes by predetermined learning goals. One indicator of learning effectiveness indicators is the value that can be obtained from the test scores. To measure the effectiveness of learning can be done by determining the learning objectives (Ozar, 2018; Triyanto, 2009). To find out whether the learning objectives have been achieved by students, then the test is given to students, one of which is a mathematical problem-solving test.

Based on the study, it can be concluded that the higher the ability possessed by students, the more effective the learning model used during learning (Widodo, 2015). This is because one of the goals of mathematics learning is to develop the ability to think critically, logically, systematically, carefully, effectively, and efficiently in solving problems (BSNP, 2006). So that the success of students, one of which can be seen from the ability of students to solve mathematical problems.

Character problems that are in accordance with mathematical problems are non-routine questions that cannot be immediately solved by only applying a specific formula, but the question challenges students to think and reason in finding the correct problem solving (Dringenberg \& Purzer, 2018; Shadiq, 2004; Widodo et al., 2018). To encourage students to be able to solve non-routine questions can be done by getting students to answer problem-based questions, using learning tools regarding students students characteristic. As is generally known that junior high school students have not been fully able to think formally, so learning media are needed as part of a learning tool that can encourage and bridge the mindset of junior high school students who are not yet fully formal.

Comics, as one of the visual media that consists of text and image elements that are presented in one frame and cannot be separated. The existence of these two elements causes the mindset of students who have not fully formal thinking can be encouraged to think formally. This is because the characteristics of comics are not yet fully considered as concrete media and also abstract, but semi-abstract media. Merging elements of text and images can familiarize students in solving non-routine questions, because completing non-routine questions presented in comics are made coherently. This is what causes the ability of students who use comics in think pair share to have better problem-solving skills.

\section{CONCLUSION}

The effectiveness of mathematics learning can be seen from the ability of students to solve mathematical problems. The results of this study indicate that the teaching of Think Pair Share models by using mathematical comics is more effective than Think Pair Share only learning. In this regard, the media should be used in mathematics learning. One alternative media that can be used in mathematics learning is mathematical comics.

\section{REFERENCES}

Acharya, B. R. (2017). Factors affecting difficulties in learning mathematics by mathematics learners. International Journal of Elementary Education, 6(2), 8-15.

Afifah, D. S. N., \& Ningrum, R. L. (2018). Critical thinking of field dependent student's in problem solving. International Journal on Teaching and Learning Mathematics, 1(1), 3138. 
Aisyah, P. N., Khasanah, S. U. N., Yuliani, A., \& Rohaeti, E. E. (2018). Analisis kemampuan pemecahan masalah matematis siswa SMP pada materi segi empat dan segi tiga. JPMI: Jurnal Pembelajaran Matematika Inovatif, 1(5), 77-83. https://doi.org/https://doi.org/10.5281/zenodo.1405906

Amalia, K., Darhim, \& Martadiputra, B. A. P. (2016). Peningkatan kompetensi strategis matematis siswa Sekolah Menengah Kejuruan (SMK) melalui strategi team-based learning. Infinity Journal, 5(1), 1-14.

Antika, L. T. (2018). The relationship between metacognition skills with the student's achievement: The implementation of reading-concept map-think pair share (Remap TPS) Model. Jurnal Pena Sains, 5(1), 19-26.

Arends, R., \& Kilcher, A. (2010). Teaching for student learning: Becoming an Accomplished teacher. New York: Taylor\&Francis Group.

Awuah, J. B., Kwarteng, E., \& Asuamah, S. Y. (2013). Perception of interest in mathematics among female teachers in teacher training colleges in Ghana. International Journal of Innovative Research and Development, 2(7), 397-402.

Baruah, T. D. (2018). E-learning as a medium for facilitating learners' support services under open and distance learning: An evaluative study. In Technology for efficient learner support services in distance education (pp. 93-112). Springer, Singapore.

Bernard, M., Nurmala, N., Mariam, S., \& Rustyani, N. (2018). Analisis kemampuan pemecahan masalah matematis siswa SMP Kelas IX pada Materi bangun datar. SJME (Supremum Journal of Mathematics Education), 2(2), 77-83.

BSNP. (2006). Peraturan Menteri pendidikan nasional Republik Indonesia no 22 tahun 2006 tentang standar isi untuk satuan dasar dan menengah. Jakarta: Mendiknas.

Buchori, A., \& Setyawati, R. D. (2015). Development learning model of charactereducation through e-comic in elementary school. International Journal of Education and Research, 3(9), 369-386.

Budiyono. (2003). Metodologi penelitian pendidikan. Surakarta: UNS Press.

Bulut, M., Akçakın, H. Ü., \& Kaya, G. (2016). The effects of GeoGebra on third grade primary students' academic achievement in fractions. International Society of Educational Research, 11(2), 347-355.

Choi, E., Lindquist, R., \& Song, Y. (2014). Effects of problem-based learning vs. traditional lecture on Korean nursing students' critical thinking, problem-solving, and self-directed learning. Nurse Education Today, 34(1), 52-56. https://doi.org/10.1016/j.nedt.2013.02.012

Creswell, J. W. (2012). Educational research: Planning, conducting and evaluating quantitative and qualitative research. London: Pearson.

Creswell, J. W., \& Creswell, J. D. (2017). Research design: Qualitative, quantitative, and mixed methods approaches. Los Angeles: Sage Publications, Inc.

Dringenberg, E., \& Purzer, Ş. (2018). Experiences of first-year engineering students working on ill-structured problems in teams. Journal of Engineering Education, 107(3), 442-467.

Elliott, B., Oty, K., Mcarthur, J., \& Clark, B. (2001). The effect of an interdisciplinary algebra/science course on students' problem solving skills, critical thinking skills and attitudes towards mathematics. International Journal of Mathematical Education in Science and Technology, 32(6), 811-816.

Erozkan, A. (2013). The effect of communication skills and interpersonal problem solving skills on social self-efficacy. Kuram ve Uygulamada Egitim Bilimleri, 13(2), 739-745. 
Fuad, N. M., Zubaidah, S., Mahanal, S., \& Suarsini, E. (2017). Improving junior high schools' critical thinking skills based on test three different models of learning. International Journal of Instruction, 10(01), 101-116.

Gazali, R. Y. (2016). Pembelajaran matematika yang bermakna. Math Didactic: Jurnal Pendidikan Matematika, 2(3), 181-190.

Hartsell, T., \& Yuen, S. C. Y. (2006). Video streaming in online learning. AACE Journal, 14(1), 31-43.

Herbst, P., Chazan, D., Chen, C. L., Chieu, V. M., \& Weiss, M. (2011). Using comics-based representations of teaching, and technology, to bring practice to teacher education courses. ZDM, 43(1), 91-103.

Huda, M. K. (2016). Penerapan Pembelajaran kooperatif tipe investigasi kelompok untuk meningkatkan kemampuan pemecahan masalah matematika siswa pada materi persamaan garis lurus. Infinity Journal, 5(1), 15-24.

Husna, Ikhsan, M., \& Fatimah, S. (2013). Peningkatan kemampuan pemecahan masalah dan komunikasi matematis siswa sekolah menengah pertama melalui model pembelajaran kooperatif tipe Think-Pair-Share (TPS). Jurnal Peluang, 1(2), 81-92.

Indaryati, \& Jailani. (2015). Pengembangan media komik pembelajaran matematika meningkatkan motvasi dan prestasi belajar siswa Kelas V. Jurnal Prima Edukasia, 3(1), 84-96.

Kristanti, F., Ainy, C., Shoffa, S., Khabibah, S., \& Amin, S. M. (2018). Developing creativeproblem-solving-based student worksheets for transformation geometry course. International Journal on Teaching and Learning Mathematics, 1(1), 13-23. https://doi.org/10.18860/ijtlm.v1i1.5581

Lin, M. H., Chen, H. C., \& Liu, K. S. (2017). A study of the effects of digital learning on learning motivation and learning outcome. Eurasia Journal of Mathematics, Science and Technology Education, 13(7), 3553-3564.

Martyanti, A., \& Suhartini. (2018). Etnomatematika: Menumbuhkan kemampuan berpikir kritis melalui budaya. Indomath: Indonesia Mathematics Edcuation, 1(1), 35-41.

Ozar, D. T. (2018). Identifying Learning Objectives and Assessing Ethics Across the Curriculum Programs. In Ethics Across the Curriculum-Pedagogical Perspectives (pp. 55-71). Springer, Cham.

Pardimin, \& Widodo, S. A. (2016). Increasing skills of student in junior high school to problem solving in geometry with guided. Journal of Education and Learning, 10(4), 390-395.

Peter, E. E. (2012). Critical thinking: Essence for teaching mathematics and mathematics problem solving skills. African Journal of Mathematics and Computer Science Research, $5(3), 39-43$.

Polya, G. (1973). How to solve it: A new aspect of mathematical method. New Jersey: Princeton University Press.

Putra, H. D., Herman, T., \& Sumarmo, U. (2017). Development of student worksheets to improve the ability of mathematical problem posing. International Journal on Emerging Mathematics Education, 1(1), 1-10.

Saragih, S. (2006). menumbuhkembangkan berpikir logis dan sikap positif terhadap matematika melalui pendekatan matematika realistik. Jurnal Pendidikan dan Kebudayaan Departemen Pendidikan Nasional (551-565). Jakarta: Badan Penelitian dan Pengembangan Depdiknas. 
Shadiq, F. (2004). Penalaran, pemecahan masalah dan komunikasi dalam pembelajaran matematika. Yogyakarta: PPPPTK Matematika.

Sugiyono. (2016). Metode penelitian pendidikan pendekatan kuantitatif, kualitatif, dan $R \& D$. Bandung: Alfabeta.

Suwarto, \& Purnami, A. S. (2018). Upaya meningkatkan pemahaman konsep matematika melalui hypothetical learning trajectory pada materi vektor. Indomath: Indonesia Mathematics Edcuation, 1(2), 69-76.

Tatalovic, M. (2009). Science comics as tools for science education and communication: A brief, exploratory study. Journal of Science Communication, 8(4), 1-17.

Toh, T. L., Cheng, L. P., Ho, S. Y., Jiang, H., \& Lim, K. M. (2017). Use of comics to enhance students' learning for the development of the twenty-first century competencies in the mathematics classroom. Asia Pacific Journal of Education, 37(4), 437-452.

Triyanto. (2009). Mendesain model pembelajaran inovatif dan progresif. Jakarta: Kencana.

Widodo, S. A. (2015). Keefektivan team accelerated instruction terhadap kemampuan pemecahan masalah dan prestasi belajar matematika siswa Kelas VIII. Kreano, Jurnal Matematika Kreatif-Inovatif, 6(2), 127-134.

Widodo, S. A. (2018). Selection of learning media mathematics for junior school students. Turkish Online Journal of Educational Technology - TOJET, 17(1), 154-160.

Widodo, S. A., Darhim, \& Ikhwanudin, T. (2018). Improving mathematical problem solving skills through visual media Improving mathematical problem solving skills through visual media. Journal of Physics: Conf. Series, 948(1), 1-6.

Widodo, S. A., \& Turmudi. (2017). Guardian Student thinking process in resolving issues divergence. Journal of Education and Learning, 11(4), 431-437. 